\title{
KAJIAN TEORITIS ATAS HARMONISASI ANTARA KESERAGAMAN (UNIFORMITY) PRAKTIK AKUNTANSI KOMERSIAL DAN FISKAL DALAM PERUSAHAAN PERBANKAN INDONESIA
}

\author{
Arie Widodo ${ }^{1}$ \\ Erwin Harinurdin ${ }^{2}$ \\ ${ }^{1}$ Laboratorium Administrasi Perpajakan Program Vokasi UI, arie.widodo.10@gmail.com \\ 2Laboratorium Administrasi Keuangan dan Perbankan Program Vokasi UI ,eharinurdin@gmail.com
}

Diterima : 1 Mei 2014

Layak Terbit : 14 Juli 2014

\begin{abstract}
Abstrak
Standar akuntansi di Indonesia yang menjadi pedoman perusahaan Perbankan dalam praktik akuntansi adalah Standar Akuntansi Keuangan (SAK) yang dikeluarkan oleh Ikatan Akuntan Indonesia (IAI), namun demikian masalah yang menonjol dalam akuntansi komersial perusahaaan perbankan dengan pajak dalam rangka menyesuaikan dengan karakteristik perusahaan perbankan diberikan pengaturan tersendiri karena menyangkut kerahasiaan nasabah. Adanya penyesuaian yang harus dilakukan terhadap laporan keuangan perusahaan untuk memenuhi ketentuan perpajakan seperti yang dilaporkan di lampiran SPT Tahunan Pajak Penghasilan Badan berupa koreksi fiskal positif maupun koreksi fiskal negatif, maka ini menjadi tujuan penelitian ini.

Walaupun akuntansi mempunyai pengaruh yang sangat besar dalam pajak namun terdapat banyak perbedaan antara akuntansi dan pajak. Perbedaan itu timbul karena adanya perbedaan tujuan antara pajak dan akuntansi. Tujuan utama akuntansi keuangan adalah untuk menyediakan informasi yang berguna kepada manajemen, para pemegang saham, para kreditur dan pihak-pihak lain yang berkepentingan. Tanggung jawab utama akuntansi adalah melindungi pihak-pihak yang berkepentingan tersebut. Sebaliknya tujuan utama sistem pajak adalah pemungutan pajak secara adil. Tujuan utama instansi perpajakan adalah melindungi kepentingan masyarakat pajak.
\end{abstract}

Kata Kunci : akuntansi, pajak, fiskal, laporan keuangan.

\begin{abstract}
Indonesian accounting standards that guide banking companies in accounting practices using the Financial Accounting Standards (IFRSs) issued by the Indonesian Institute of Accountants (IAI), however, the accounting problems that stand in the commercial banking firms with a tax in order to adapt to the characteristics of the banking company given the setting of its own because it involves customer confidentiality. Adjustments to be made to the company's financial statements to comply with taxation as reported in the annex SPT Corporate Income Tax fiscal correction in the form of positive and negative fiscal correction, it is the goal of this research.

Although accounting have enormous influence in taxes, but there are many differences between the accounting and tax. The difference arises because of the differences between tax and accounting purposes. The main purpose of financial accounting is to provide useful information to management, shareholders, creditors and other parties concerned. The primary responsibility of accounting is to protect the interested parties are. Instead the main purpose of the tax system is fair taxation. The main purpose is to protect the interests of the tax authorities the tax community.
\end{abstract}

Keywords: accounting, tax, fiscal, financial statements

\section{PENDAHULUAN}

1. Latar Belakang

Kinerja lembaga keuangan yang sehat dan berkelanjutan (sustainable) ditentukan oleh efisiensi baik dari sudut pandang mikro maupun makro (Berger and Mester : 1997). Dari perpektif mikro, dalam suasana persaingan yang semakin ketat sebuah bank agar bisa bertahan dan berkembang harus efisien dalam kegiatan operasinya. Bank-bank yang tidak efisien, besar kemungkinan akan 
exit dari pasar karena tidak mampu bersaing dengan kompetitornya, baik dari segi harga (pricing) maupun dalam hal kualitas produk dan layanan. Bank yang tidak efisien akan kesulitan dalam mempertahankan kesetian nasabahnya dan juga tidak diminati oleh calon nasabah dalam rangka untuk memperbesar customer base-nya.

Sementara dari perspektif makro, industri perbankan yang efisien dapat mempengaruhi biaya intermediasi keuangan dan secara keseluruhan stabilitas sistem keuangan. Hal ini disebabkan peran yang sangat strategis dari industri perbankan sebagai intermediator dan produser jasa-jasa keuangan. Dengan tingkat efisiensi yang lebih tinggi, kinerja perbankan akan semakin lebih baik dalam mengalokasikan sumberdaya keuangan dan pada akhirnya dapat meningkatkan kegiatan investasi dan pertumbuhan ekonomi ( Weill : 2003).

Bank merupakan suatu badan usaha di bidang keuangan yang menghimpun dana dari masyarakat dalam bentuk simpanan dan menyalurkannya kepada masyarakat dalam bentuk kredit dan atau bentuk-bentuk lainnya dalam rangka meningkatkan taraf hidup orang banyak (Dendawijaya : 2001 : 12). Dalam melaksanakan kegiatan usahanya sebagaimana tersebut di atas bank harus berpedoman kepada perangkat hukum yang terkait, antara lain Undang-Undang No. 7 Tahun 1992 sebagaimana telah diubah dengan UndangUndang No. 10 Tahun 1998 tentang Perbankan ("UU Perbankan"). Seiring dengan meningkatnya kegiatan pembangunan, meningkat pula kebutuhan terhadap pendanaan, yang sebagian besar dana yang diperlukan untuk memenuhi kebutuhan perekonomian diperoleh melalui kegiatan pinjam-meminjam (Supriyanto : $2006: 115$ ).

Informasi kinerja suatu bank dapat dilihat dari laporan keuangan (neraca dan laporan labarugi). Neraca berisi informasi aset, kewajiban dan modal pada suatu waktu. Laporan labarugi berisi informasi mengenai hasil aktivitas bisnis dalam kurun waktu tertentu. Aset bank berupa cadangan (reserves), surat berharga dan kredit (loans). Kewajiban berupa simpanan masyarakat (dana pihak ketiga) dan kewajiban lainnya (non deposits). Selisih nilai aset dan kewajiban adalah kekayaan bersih (net worth) atau modal (capital).

Standar akuntansi di Indonesia yang menjadi pedoman perusahaan Perbankan dalam praktik akuntansi adalah Standar Akuntansi Keuangan (SAK) yang dikeluarkan oleh Ikatan Akuntan Indonesia (IAI). Namun demikian masalah yang menonjol dalam akuntansi komersial perusahaaan perbankan dengan pajak dalam rangka menyesuaikan dengan karakteristik perusahaan perbankan diberikan pengaturan tersendiri karena menyangkut kerahasiaan nasabah.

Dalam Pedoman Akuntansi Perbankan Indonesia dinyatakan laporan keuangan bank bertujuan untuk menyediakan informasi yang menyangkut posisi keuangan, kinerja serta perubahan posisi keuangan. Selain itu laporan keuangan bank juga bertujuan untuk pengambilan keputusan. Suatu laporan keuangan akan bermanfaat apabila informasi yang disajikan dalam laporan keuangan tersebut dapat dipahami, relevan, andal dan dapat diperbandingkan. Akan tetapi, perlu disadari pula bahwa laporan keuangan tidak menyediakan semua informasi yang mungkin dibutuhkan oleh pihak-pihak yang berkepentingan dengan bank, karena secara umum laporan keuangan hanya menggambarkan pengaruh keuangan dari kejadian masa lalu, dan tidak diwajibkan untuk menyediakan informasi non-keuangan. Walaupun demikian, dalam beberapa hal bank perlu menyediakan informasi nonkeuangan yang mempunyai pengaruh keuangan di masa depan.

Menurut Gunadi (1997 : 20), praktik Akuntansi yang mengikuti standar akuntansi keuangan cenderung kurang memahami kebutuhan seluruh pengguna laporan keuangan, karena memang akuntansi itu dipengaruhi oleh faktor-faktor sosial, politik, ekonomi, hukum dan waktu. Sehubungan dengan penetapan besarnya penghasilan yang menjadi basis pengenaan pajak dengan mendasarkan pada undang-undang perpajakan, pemerintah sebagai salah satu pengguna laporan keuangan mempunyai sudut pandang tersendiri untuk menentukan besarnya penghasilan dan biaya yang dikeluarkan oleh suatu perusahaan. Kecenderungan perbedaan pengakuan dan persepsi ini pada akhirnya akan menguatkan perbedaan di antara kedua pihak dalam pengakuan, pengukuran dan pencatatan transaksi.

Dengan pengertian dan pembatasan yang berbeda, pengakuan penghasilan dan biaya juga mempunyai perbedaan antara pengakuan 
menurut akuntansi dan pengakuan menurut perpajakan. Karena ditetapkan dengan undang-undang, perpajakan menjadi sesuatu norma yang harus diikuti. Keharusan mengikuti peraturan perpajakan ini memaksa Wajib Pajak untuk melakukan penyesuaian.

Di Indonesia, ada dua jenis perbedaan dalam perlakuan pos rekening yang mempengaruhi penghitungan laba rugi (Tjahjono, 1997: 501), yaitu: "pertama, perbedaan tetap adalah transaksi-transaksi pendapatan dan biaya tertentu yang boleh diakui akuntansi tetapi tidak boleh diakui oleh pajak (peraturan pajak) atau sebaliknya. Kedua, perbedaan waktu adalah perbedaan pengakuan pendapatan atau biaya untuk penghitungan laba". Perbedaan waktu hanya menyebabkan perbedaan laba sebelum pajak dengan laba kena pajak antar periode saja sedangkan secara akumulasi (totalnya) tidak menyebabkan adanya perbedaan. Atau perbedaan di satu atau beberapa periode akan tertutup oleh periode yang lainnya. Perbedaan tersebut terjadi salah satunya karena terdapat perbedaan metode akuntansi yang berbeda dalam konsep akuntansi yang selanjutnya didasarkan pada SAK dengan peraturan perpajakan yang selanjutnya didasarkan pada Peraturan Perpajakan yang berlaku di Indonesia.

Dalam akuntansi, semua barang atau jasa yang digunakan untuk merealisasikan pendapatan dalam suatu periode akuntansi disebut sebagai biaya, tetapi dalam perpajakan, konsep biaya dibedakan menjadi biaya yang dapat dikurangkan dari penghasilan bruto (deductible expense) dan biaya yang tidak dapat dikurangkan dari penghasilan bruto (nondeductible expense). Dengan kata lain, tidak semua biaya (dalam pengertian akuntansi) dapat sebagai pengurang penghasilan bruto dalam perpajakan.

Pada umumnya keputusan yang diambil oleh pihak manajemen sebagian besar berdasarkan pada informasi akuntansi dan analisis-analisisnya. Salah satu bentuk informasi akuntansi yang dilaporkan kepada manajemen antara lain berupa laporan keuangan yang terdiri dari laporan laba rugi dan neraca. Laporan laba rugi mengambarkan pendapatan dan biaya untuk suatu periode akuntansi. Pendapatan merupakan penghasilan perusahaan yang berasal dari kegiatan utama maupun yang tidak utama bagi perusahaan. Sedangkan biaya dapat berupa biaya operasional yang berasal dari kegiatan perusahaan. Neraca menggambarkan aktiva, hutang dan modal perusahaan. Aktiva tersebut terdiri dari aktiva lancar dan aktiva tetap. Aktiva lancar terdiri dari kas, piutang usaha, persediaan dan sebagainya. Sedangkan aktiva tetap terbagi dari dua bagian yaitu aktiva tetap berwujud dan aktiva tetap tidak berwujud.

Kebijakan tersebut harus mencerminkan prinsip kehati-hatian dan mencakup semua hal yang material dan sesuai dengan ketentuan dalam PSAK. Apabila PSAK belum mengatur masalah pengakuan, pengukuran, penyajian atau pengungkapan dari suatu transaksi atau peristiwa, maka manajemen harus menetapkan kebijakan untuk memastikan bahwa laporan keuangan menyajikan informasi:

a. relevan terhadap kebutuhan para pengguna laporan untuk pengambilan keputusan; dan b. dapat diandalkan, dengan pengertian:

1) mencerminkan kejujuran penyajian hasil dan posisi keuangan perusahaan;

2) menggambarkan substansi ekonomi dari suatu kejadian atau transaksi dan tidak semata-mata bentuk hukumnya;

3) netral, yaitu bebas dari keberpihakan;

4) mencerminkan kehati-hatian; dan

5) mencakup semua hal yang material.

Slemrod (1992) menyatakan bahwa peraturan yang kompleks dapat membuat Wajib Pajak kesulitan memenuhi kewajiban pajaknya, sehingga membuat mereka harus mengeluarkan biaya dan aktivitas ekstra yang tidak sedikit untuk urusan pajak. Sedangkan peraturan yang sederhana mungkin tidak dapat memenuhi tujuan dari pengenaan pajak sebagaimana yang diharapkan oleh negara (pemerintah).

Kerelaan untuk memenuhi peraturan perpajakan tidak akan dapat dicapai apabila Wajib Pajak ternyata tidak cukup mampu menguasai peraturan perpajakan karena kerumitan dan multitafsir yang melekat pada peraturan tersebut. Dengan demikian, pemenuhan peraturan perpajakan juga mensyaratkan suatu tingkat kompleksitas yang rendah. Peraturan perpajakan perlu dibuat sederhana atau lengkap tapi jelas sebagaimana dikemukakan oleh Ronald B Hegt, seorang anggota Komite Eksekutif Perpajakan AICPA, bahwa : 
"By and large, small businesses obey the law, but it's only human to inadvertently disobey a law if you do not or cannot understand the rules. The lack of deliberation in the legislative process, the frequent law changes in recent years, and the increasing magnitude and complexity of the internal revenue Code create serious compliance issues for small business. The AICPA has long understood the consequences of tax law complexity and has supported effort to move toward a simpler tax system."

Perbedaan persepsi yang muncul dari kompleksitas peraturan perpajakan seperti uraian di atas mempunyai keterkaitan juga dengan adanya perbedaan praktik akuntansi antara komersial dan fiskal. Adanya perbedaan praktik akuntansi antara komersial dan fiskal seperti di Indonesia ini dalam praktiknya terjadi juga dibanyak negara. Penelitian yang dilakukan oleh Feydeau dan Kulbokas di Perancis membuktikan bahwa variabel keseragaman antara praktik akuntansi komersial dan praktik akuntansi fiskal mempengaruhi kepatuhan Wajib Pajak. Berdasarkan hasil penelitian yang dilakukan oleh Feydeau dan Kulbokas, Sandford menegaskan bahwa harmonisasi pembukuan untuk tujuan komersial dan tujuan fiskal tidak membutuhkan sumber daya ataupun aktivitas ekstra sehingga tidak berdampak pada timbulnya biaya ekstra. Sebaliknya, perbedaaan pembukuan untuk tujuan komersial dan tujuan fiskal yang terlalu banyak membutuhkan sumber daya ataupun aktivitas ekstra yang berdampak pada timbulnya biaya ekstra yang akan berpengaruh terhadap kepatuhan Wajib Pajak dalam memenuhi kewajibannya.

Banyak faktor yang diindikasikan mempunyai pengaruh terhadap kepatuhan pajak dan biaya kepatuhan Wajib Pajak. Dengan demikian, seperti yang telah dinyatakan sebelumnya oleh Feydeau dan Kulbokas (1989 : 361-386) bahwa semakin seragam perlakuan pembukuan antara akuntansi komersial dan akuntansi fiskal, semakin tinggi kepatuhan pajak dan rendahnya biaya kepatuhan.

Dalam undang-undang perpajakan di Indonesia, jika diperhatikan lebih mendalam terdapat dua hal yang perlu mendapat perhatian yang berpotensi mempengaruhi tingkat kepatuhan Wajib Pajak, yaitu (1) spirit of punishment; dan (2) kompleksitas.
Undang-undang perpajakan tersebut masih menonjolkan aspek pemberian punishment dari pada spirit pemberian reward. Di lain pihak, aturan perpajakan tersebut cenderung kompleks atau menambah keruwetan dalam menerapan di lapangan. Kecenderungan ini dapat memberikan peluang untuk menimbulkan kerancuan dalam memahami dan menginterpretasikannya.

Sistem self-assessment yang memberikan kepercayaan dan tanggung jawab kepada Wajib Pajak untuk menghitung, menyetor, dan melaporkan sendiri pajak yang terhutang, mengharuskan Wajib Pajak untuk memenuhi kewajiban pajak dengan baik sesuai dengan peraturan perundang-undangan perpajakan yang berlaku. Upaya untuk melaksanakan pemenuhan kewajiban pajak dengan baik dan benar agar tidak terjadi pemborosan sumber dana tidak perlu karena sanksi perpajakan (bunga, denda maupun kenaikan pajak), maka Wajib Pajak harus mengatur kewajiban perpajakannya secara sistematis yang meliputi: perencanaan, pengorganisasian, pelaksanaan dan pengendalian dibidang perpajakan untuk mencapai pemenuhan kewajiban perpajakan yang minimum.

\section{Metode Penelitian}

Terdapatnya tujuan dan kepentingan yang berbeda antara pajak dan akuntansi, maka laporan keuangan yang dihasilkan akan berbeda antara laporan untuk tujuan akuntansi dengan laporan untuk tujuan perpajakan. Oleh karena itu, yang mungkin dilakukan di Indonesia ialah harmonisasi akuntansi dan pajak. Untuk itu peneliti perlu melakukan penelitian tentang harmonisasi akuntansi dan pajak.

Adanya penyesuaian yang harus dilakukan terhadap laporan keuangan perusahaan untuk memenuhi ketentuan perpajakan seperti yang dilaporkan di lampiran SPT Tahunan Pajak Penghasilan Badan berupa koreksi fiskal positif maupun koreksi fiskal negatif, maka Wajib Pajak harus memperhatikan standar akuntansi keuangan dan peraturan perpajakan. Maka dari uraian di atas pertanyaan penelitian adalah sebagai berikut: Bagaimana harmonisasi keseragaman (uniformity) praktik laporan akuntansi komersial dan laporan fiskal pada perusahaan perbankan di Indonesia?

Untuk menjelaskan dan menguraikan keseragaman (uniformity) praktik laporan 
akuntansi komersial dan laporan akuntansi fiskal pada perusahaan perbankan di Indonesia. Signifikansi penelitian meliputi signifikansi akademis dan signifikansi praktis, secara akademis. Signifikansi akademis dari hasil penelitian diharapkan memperkaya teori pemajakan optimal normatif dalam kaitannya dengan keseragaman (uniformity) praktik laporan akuntansi komersial dan fiskal. Signifikansi praktis penelitian ini diharapkan dapat menjadi acuan dalam merencanakan pelaporan pajaknya.

\section{Tinjauan Literatur.}

Feydeau dan Kulbokas (1989 : 361-386) melakukan penelitian di Perancis yang menunjukan hasil bahwa semakin seragam (uniformity) perlakuan pembukuan untuk tujuan komersial dan tujuan fiskal, semakin tinggi kepatuhan pajak demikian pula sebaliknya. Kepatuhan pajak dijelaskan sebagai kondisi ideal Wajib Pajak yang memenuhi ketentuan peraturan perpajakan dengan melaporkan pendapatan kena pajak secara benar dan lengkap. Adapun konsep kepatuhan pajak pada penelitian ini merujuk pada Yoingco (1997) yang membagi kepatuhan pajak dalam tiga aspek yang terdiri dari : aspek formal, material (honestly) dan pelaporan (reporting).

Adinur Prasetyo (2007) meneliti apakah terdapat Pengaruh Keseragaman Praktik Akuntansi Komersial dan Fiskal serta kesamaan Persepsi Fiskus dalam penafsiran Peraturan Perpajakan dan Ukuran Perusahaan Terhadap Kepatuhan Pajak. Penelitian ini juga menemukan bahwa Keseragaman praktik akuntansi serta kesamaan persepsi dan ukuran perusahaan berhubungan dan berpengaruh terhadap kepatuhan pajak.

Masalah keseragaman praktik akuntansi untuk tujuan komersial dan tujuan fiskal atau uniformity, dengan demikian lebih mendapat perhatian. Akhirnya, proporsi pengaruh keseragaman (uniformity) terhadap kepatuhan pajak di uji melalui bukti empiris dengan generalisasi yang menggunakan teknik regresi.

Perusahaan pertambangan yang biasanya merupakan perusahaan penanaman modal asing, perlu mendapat perhatian dalam menerapkan sistem akuntansinya. Perpajakan sangat erat kaitannya dengan akuntansi. Pembukuan merupakan sarana informasi bagi
Wajib Pajak untuk mengisi SPT Tahunan Pajak Penghasilan secara lengkap dan benar serta merupakan alat pembuktian apabila administrasi perpajakan melaukan pemeriksaan untuk menguji kepatuhan pemenuhan kewajiban perpajakan.

Penghasilan yang dihitung menurut pembukuan Wajib Pajak yang didasarkan kepada standar akuntansi keuangan berbeda dengan penghasilan kena pajak yang dihitung berdasarkan ketentuan pajak. (Sitorus : 2001: 1). Mengutip artikel Leo Herbert (1972 : 31) dalam Syafri (1999 : 25) bahwa di Amerika serikat dalam tahun 1900 akuntansi sudah dianggap dapat memberikan laporan tentang pajak, dan pada tahun 1925 mulai diperkenalkan akuntansi untuk perpajakan.

\section{Keseragaman (Uniformity)}

Dalam sistem pemajakan (pajak penghasilan) dikenal istilah self-assessment system dan official assessment system. Self assessment system adalah suatu system pemajakan yang memberikan kepercayaan kepada masyarakat atau Wajib Pajak untuk melakukan pemenuhan kewajiban pajaknya, mulai dari pendaftaran untuk memperoleh NPWP, menghitung, menyetorkan pajak, melaporkan, hingga mempertanggungjawabkan pajak terhutang (Asikin : $1991: 185$ ).

Sistem self assessment dalam pemungutan pajak penghasilan mulai diberlakukan di Indonesia sejak tahun 1984. Dalam perkembangannya, system self assessment di Indonesia mengenal dua macam tipe sistem pemajakan, yaitu : semi self assessment dan full self assessment. Dalam semi self assessment, Wajib Pajak belum diberi wewenang sepenuhnya untuk menetapkan pajak terhutang. sedangkan, pada system full self assessment, proses dan penetapan sudah berada pada Wajib Pajak yang diwujudkan dalam Surat Pemberitahuan (SPT) Pajak secara lengkap, benar dan jelas dan semua lampiran sudah disertakan. SPT Tahunan sumbernya berasal dari laporan keuangan yang disusun berdasarkan SAK, karena ada perbedaan aturan antara SAK dan peraturan perpajakan maka mengakibatkan adanya perbedaan perlakuan. (Sitorus : $2001: 1$ )

Pedoman ini mempunyai potensi timbulnya perbedaan treatment dan beda persepsi antara Wajib Pajak dan fiskus, yakni : (1) terjadinya perbedaan antara pengakuan pendapatan serta beban menurut standar akuntansi yang 
berlaku umum dan pengakuan menurut peraturan perpajakan, serta (2) perbedaan persepsi antara fiskus dan Wajib Pajak dalam penafsiran peraturan perpajakan. (Syafri : $1999: 26)$

Adanya perbedaan praktik akuntansi antara komersial dan fiskal di banyak negara dalam praktiknya terjadi juga seperti di Indonesia. Adinur Prasetyo (2007) meneliti apakah terdapat Pengaruh Keseragaman Praktik Akuntansi Komersial dan Fiskal serta kesamaan Persepsi Fiskus dalam penafsiran Peraturan Perpajakan dan Ukuran Perusahaan Terhadap Kepatuhan Pajak. Penelitian ini juga menemukan bahwa keseragaman praktik akuntansi serta kesamaan persepsi dan ukuran perusahaan berhubungan dan berpengaruh terhadap kepatuhan pajak.

Penelitian yang dilakukan oleh Feydeau dan Kulbokas di Perancis membuktikan bahwa variabel keseragaman antara praktik akuntansi komersial dan praktik akuntansi fiskal mempengaruhi kepatuhan pajak. Berdasarkan hasil penelitian yang dilakukan oleh Feydeau dan Kulbokas, Sandford menegaskan bahwa harmonisasi pembukuan untuk tujuan komersial dan tujuan fiskal tidak membutuhkan sumber daya ataupun biaya ekstra sehingga tidak berdampak pada timbulnya ketidakpatuhan. Sebaliknya, perbedaan pembukuan untuk tujuan komersial dan tujuan fiskal yang terlalu banyak membutuhkan sumber daya ataupun biaya ekstra yang berdampak pada timbulnya ketidakpatuhan.

Penelitian yang juga dilakukan oleh Lilian $\mathrm{F}$ Mills (1996 : 431) di Amerika Serikat juga menunjukkan adanya penyesuaian yang harus dilakukan terhadap laporan keuangan perusahaan untuk memenuhi ketentuan perpajakan. Penelitian menunjukkan hasil bahwa perusahaan harus mengeluarkan biaya ekstra mencapai rata-rata US $\$ 200.000$ atau 0.33\% dari pajak terhutang untuk aktivitas ektra guna memenuhi ketentuan atau kepatuhan perpajakan dan mengupayakan agar perusahaan tidak membayar pajak lebih dari yang seharusnya. Dengan demikian dapat disimpulkan bahwa semakin besar uniformity (yang diartikan sebagai harmonisasi pembukuan untuk tujuan komersial dan tujuan fiskal) maka semakin tinggi kepatuhan pajak.
Informasi dalam laporan keuangan.

Akhir tahun adalah saat dimana perusahaan membuat laporan keuangan untuk memenuhi kepentingan berbagai pihak yang menggunakannya. Pengguna informasi dalam laporan keuangan pada dasarnya dapat dibedakan menjadi dua kelompok yaitu kelompok internal (manajemen dan karyawan) dan kelompok eksternal (investor/calon investor, kreditor/calon kreditor, pelanggan, pemerintah, masyarakat).

Pihak internal khususnya manajemen sangat berkepentingan terhadap laporan keuangan yang dibuatnya karena informasi tersebut akan digunakan untuk membuat perencanaan, pengendalian dan pengambilan keputusan. Pihak ekstern (pemerintah) laporan keuangan khususnya dipakai untuk kepentingan fiskal (perpajakan). Terutama laporan laba rugi yang berisi informasi untuk menentukan pajak penghasilan yang harus ditanggung oleh perusahaan tersebut. Lebih lanjut informasi tersebut digunakan untuk mengetahui apakah pajak yang telah dibayarkan oleh perusahaan sebagai Wajib Pajak badan atau orang pribadi yang wajib melakukan pembukuan telah memenuhi persyaratan sesuai dengan ketentuan perpajakan yang berlaku.

Sebagai Wajib Pajak maka pada suatu tanggal tertentu yang telah ditetapkan harus menyampaikan informasi tentang penghasilan yang dikenakan pajak melalui penyerahan SPT (Surat Pemberitahuan) - dalam hal ini SPT Tahunan Pajak Penghasilan. Salah satu fungsi SPT ini adalah sebagai sarana untuk melaporkan dan mempertanggungjawabkan perhitungan pajak yang sebenarnya terutang atau harus dibayar. Oleh karena sistem pemungutan pajak yang dianut di negara kita adalah Self Assestment System dimana Wajib Pajak diberi wewenang penuh untuk menentukan besarnya pajak terutang mulai menghitung, menyetor dan melaporkan sendiri pajak yang terutang (mengisi sendiri SPT), maka dalam penyampaian SPT nantinya harus melaporkan bukti-bukti yang mendukung penghitungan pajak terutang. Bagi Wajib Pajak yang mengadakan pembukuan, bukti tersebut berupa laporan keuangan (Neraca dan Laporan Laba Rugi) serta keterangan-keterangan lain yang diperlukan untuk menghitung besarnya penghasilan kena pajak, seperti daftar penghitungan penyusutan, daftar piutang 
yang dihapuskan, penghitungan alokasi biaya kantor pusat dan biaya lainnya.

Dari segi akuntansi, pedoman penyusunan laporan keuangan di Indonesia diatur dalam Standar Akuntansi Keuangan, sedangkan dalam hal penghitungan pajak yang terutang pedoman yang digunakan adalah Peraturan Perpajakan. Standar Akuntansi Keuangan (SAK) sendiri tidak secara spesifik mengatur akuntansi terhadap Pajak Penghasilan. Namun Pernyataan Standar Akuntansi Keuangan (PSAK) Nomor 46 adalah PSAK yang mengatur bagaimana perusahaan melaporkan pajak penghasilan dalam struktur laporan keuangan baik dalam laporan posisi keuangan (neraca) maupun dalam laporan laba rugi. Biaya pajak penghasilan selama ini dianggap sama dengan utang pajak penghasilan (kas) yang penghitungannya didasarkan pada laba (penghasilan) menurut perpajakan. Di sisi lain, laporan keuangan yang dibuat perusahaan lebih banyak ditujukan untuk kepentingan eksternal (individual investor) sebagai pertimbangan dalam membuat keputusan ekonomik dan pihak internal untuk kepentingan perencanaan, pengendalian dan pengambilan keputusan.

Oleh karena itu perusahaan-perusahaan besar mengutamakan menyusun laporan keuangan komersial untuk menunjukkan informasi yang realistis. Laporan laba rugi yang disusun secara komersial tersebut menghasilkan laba sebelum pajak, sedangkan laporan laba rugi fiskal menghasilkan laba kena pajak. Ketidaksamaan antara pedoman dalam SAK dengan dalam peraturan perpajakan membuat penghitungan laba sebelum pajak berbeda dengan laba kena pajak yang salah satunya adalah digunakannya dasar akrual dalam akuntansi sementara dalam peraturan perpajakan tidak secara murni digunakan dasar akrual tersebut ataupun murni dasar tunai. Laba sebelum pajak (pre tax financial income) adalah laba untuk tujuan pelaporan keuangan, merupakan hasil pembandingan pendapatan dengan beban berdasarkan ketentuan SAK. Laba kena pajak (taxable income) adalah laba untuk tujuan pajak ("Penghasilan Kena Pajak"), merupakan istilah yang digunakan untuk menunjukkan jumlah tertentu sebagai dasar penghitungan pajak penghasilan yang terutang. Pada saat menghitung pajak penghasilan yang akan dibayar (terutang) yang berdasar laba kena pajak tersebut, perusahaan mungkin hanya melakukan penyesuaian laba rugi komersial atau bahkan membuat dua laporan keuangan untuk memenuhi kepentingan yang berbeda tersebut.

Negara-negara tertentu tidak membedakan laba kena pajak dan laba sebelum pajak. Dalam kondisi yang demikian, memilih konsep laba mana yang digunakan sebagai dasar penghitungan pajak penghasilan maupun mencari penyebab perbedaannya tidaklah perlu. Di Amerika Serikat, akuntansi terhadap pajak penghasilan masih menjadi isu yang kontroversial terutama pada masalah alokasi Pajak Penghasilan akibat dari timing differences.

Penelitian ini akan membahas mengenai penyebab perbedaan penghitungan laba sebelum pajak menurut akuntansi (pendekatan komersial) dengan laba kena pajak menurut peraturan perpajakan (pendekatan fiskal). Perbedaan pedoman dalam akuntansi dengan perpajakan juga secara tidak langsung akan membuat laporan keuangan komersial (dibuat berdasar Standar Akuntansi Keuangan), yang biasannya untuk memenuhi kepentingan pemakai secara umum berbeda dengan laporan keuangan fiskal (dibuat berdasar peraturan perpajakan), yang biasanya dibuat untuk memenuhi kepentingan perpajakan (fiskus). Pembahasan juga disertai dengan ilustrasi sederhana mengenai pengaruh perbedaan-perbedaan tersebut dan bagaimana penyesuaiannya untuk memperoleh laporan keuangan fiskal. Sehingga meskipun terdapat perbedaan kepentingan antar pemakainya tetapi perusahaan tidak perlu membuat dua atau lebih laporan keuangan yang berbeda. Khususnya dalam penyajian laporan laba rugi, jumlah laba sebelum pajak disesuaikan/ direkonsiliasi dengan menambahkan atau mengurangkan jumlah perbedaan tersebut sehingga diperoleh jumlah laba kena pajak yang benar menurut ketentuan perpajakan yang berlaku.

\section{Metode Penelitian}

Untuk mengetahui bagaimana harmonisasi keseragaman (uniformity) praktik laporan akuntansi komersial dan laporan fiskal pada perusahaan perbankan di Indonesia sesuai dengan butir-butir rumusan masalah, tujuan, dan manfaat penelitian, maka digunakan pendekatan penelitian menggunakan metode 
penelitian kualitatif. Penelitian ini termasuk dalam penelitian post positivism. Post positivism mengangap bahwa "fakta" itu sejauh menyangkut masyarakat dan manusia bukan hanya realitas yang ada sekarang, melainkan juga punya hubungan dengan masa lampau dan masa yang akan datang. Metode kualitatif juga dipilih karena metode kualitatif dapat memberi rincian yang kompleks tentang fenomena yang sulit diungkapkan oleh metode kuantitatif. (Anselm and Juliet: $2003: 5)$

Jenis penelitian yang digunakan adalah metode dekriptif kualitatif yang dilakukan untuk mengetahui bagaimana harmonisasi keseragaman (uniformity) praktik laporan akuntansi komersial dan laporan fiskal pada perusahaan perbankan di Indonesia. Adapun alasan menggunakan deskriptif adalah merujuk pada pendapat Neuman (1999: 31) yang menyatakan bahwa deskriptif artinya melukiskan variabel-demi variabel, satu demi satu. Dalam melakukan penelitian ini, penulis akan mengumpulkan data dari dua sumber, yaitu : studi kepustakaan dan dokumenter. Analisis data kualitatif adalah analisis yang dilakukan terhadap data-data non-angka seperti hasil wawancara atau catatan laporan bacaan dari buku-buku, artikel, dan termasuk non tulisan seperti foto, gambar atau film, dengan tujuan mencari suatu pola umum dalam bentuk diskripsi kata-kata. (Irawan : 2004: 99).

\section{HASIL DAN PEMBAHASAN}

Perbedaan Tujuan atau Sasaran Perusahaan Pada dasarnya terdapat berbagai rumusan tentang tujuan perusahaan yang biasanya tidak merupakan satu kesatuan tetapi tujuan tersebut bahkan mengandung makna ganda. Di satu sisi, financial objectives suatu perusahaan (Sofyan Syafri ; 1999 : 23) adalah :

a) memaksimalkan return on assets,

b) memaksimalkan shareholders' ataupun stakehoders' wealth,

c) memaksimalkan net income atau yang lain.

Sedangkan di sisi yang lain, taxation objectivenya adalah meminimalkan pembayaran pajak (minimizing tax-payments) terutama perusahaan-perusahaan non BUMN dan BUMD - tentunya dengan memperhatikan peraturan perundangundangan yang berlaku. Kedua tujuan tersebut nampaknya bertentangan satu dengan yang lainnya sehingga membuat tidak terdapatnya complete agreement antara laba akuntansi (accounting-income / pre tax financial income) dengan laba kena pajak (taxable-income). Tugas manajemen adalah justru mencari atau bahkan menciptakan variabel-variabel yang membuat perbedaan tersebut yang berakibat berkurangnya pajak yang terutang sehingga tujuan minimisasi pajak tidak dipandang sebagai tujuan yang terpisah dengan tujuan finansialnya.

\section{Perbedaan ekonomis}

Perbedaan kedua pendekatan (komersial dan fiskal) juga akan bermakna ekonomis dalam pengambilan keputusan, tidak hanya bagi pihak eksternal tetapi juga bermakna ekonomis bagi pihak internal seperti manajemen suatu perusahaan. Manajemen biasanya dituntut untuk paling tidak mengambil suatu keputusan terutama dalam hal (Sofyan Syafri : 1999 : 30) : a) investasi, b) pendanaan dan c) dividen.

Keputusan yang diambil manajemen merupakan pilihan satu diantara berbagai alternatif yang tersedia. Oleh karena itu dalam mengambil suatu keputusan, manajemen harus selalu mempertimbangkan hal-hal yang dianggap relevan baik dari segi revenue, cost, time value of money maupun dari segi lain.

Ketiga keputusan tersebut juga tidak terlepas dari salah satu variabel yang mempengaruhi yaitu pajak khususnya pajak penghasilan. Keputusan investasi misalnya, informasi relevan yang perlu dipertimbangkan adalah aliran kas masuk setelah pajak (after-tax cash flows), yang berarti memasukkan pajak sebagai salah satu variabel penghitungannya. Demikian pula dalam kaitannya dengan keputusan pendanaan, informasi relevan dalam pengambilan keputusan tersebut adalah biaya modal sesudah pajak (after-tax cost of 
capital). Keputusan dividen hendaknya mempertimbangkan dua faktor penting yaitu liquidity test dan bankruptcy test.

\section{Area Perbedaan}

Faktor-faktor yang menyebabkan perbedaan laba sebelum pajak menurut akuntansi dengan laba kena pajak menurut perpajakan secara lebih rinci dikategorikan dalam (Sitorus : 2001 : 40-44): 1) Perbedaan waktu (timing/temporary differences); Timing differences (Perbedaan Waktu/Sementara) didefinisikan oleh APB (FASB, 1989: 151 dalam Sugiri hal 80) sebagai: "perbedaanperbedaan antara periode-periode pengakuan transaksi-transaksi yang mempengaruhi laba kena pajak (taxable income) dan periodeperiode pengakuan transaksi-transaksi tersebut dalam penentuan laba akuntansi sebelum pajak". Setiap timing differences berasal dari satu periode akuntansi tertentu yang mempengaruhi laba kena pajak atau laba akuntansi dan kemudian berbalik pada satu atau lebih periode berikutnya. Empat tipe transaksi yang akan menimbulkan timing differences diuraikan sebagai berikut:

- Pendapatan atau keuntungan dimasukkan ke dalam laba kena pajak pada periode sesudah pos-pos tersebut dimasukkan dalam laba akuntansi sebelum pajak

- Beban/biaya atau kerugian dikurangkan dalam penentuan laba kena pajak pada periode sesudah pos-pos tersebut dikurangkan dalam penentuan laba akuntansi sebelum pajak.

- Pendapatan atau keuntungan dimasukkan ke dalam laba kena pajak pada periode sebelum pos-pos tersebut dimasukkan ke dalam laba akuntansi sebelum pajak.

- Beban/biaya atau kerugian dikurangkan dalam penentuan laba kena pajak pada periode sebelum pos-pos tersebut dikurangkan dalam penentuan laba akuntansi sebelum pajak.

\section{2) Perbedaan permanen (permanent differences)}

Permanent differences (perbedaan permanen/tetap) didefinisikan oleh APB
(Klinger dan Savage, 1988 dalam Sugiri) sebagai: "perbedaan-perbedaan antara laba kena pajak dan laba akuntansi sebelum pajak yang muncul dari transaks-transaksi yang berdasarkan UU atau aturan perpajakan, tidak akan terhapus oleh selisih-selisih yang bersangkutan pada periode-periode yang lain”. Di Indonesia, ada dua bentuk perbedaan dalam perlakuan pos rekening yang mempengaruhi penghitungan laba rugi (Tjahjono, 1997: 501), yaitu: "Pertama, perbedaan tetap adalah transaksi-transaksi pendapatan dan biaya tertentu yang boleh diakui akuntansi tetapi tidak boleh diakui oleh pajak (peraturan pajak) atau sebaliknya. Kedua, perbedaan waktu adalah perbedaan pengakuan pendapatan atau biaya untuk penghitungan laba”. Suatu transaksi pendapatan atau biaya sudah diakui akuntansi sehingga dilaporkan (dibukukan) dalam laporan keuangan periode tertentu tetapi menurut perpajakan diperhitungkan pada periode yang berbeda (ataupun dicatat dengan jumlah yang berbeda), dan sebaliknya.

Dengan demikian perbedaan waktu ini hanya menyebabkan perbedaan laba sebelum pajak dengan laba kena pajak antar periode saja sedangkan secara akumulasi (totalnya) tidak menyebabkan adanya perbedaan. Atau perbedaan di satu atau beberapa periode akan tertutup oleh periode yang lainnya.

\section{Area Perbedaan Laporan Keuangan}

Area perbedaan dalam laporan keuangan meliputi perbedaan waktu dan perbedaan tetap, perbedaan waktu adalah menyangkut perbedaan waktu atas pembebanan biaya dan pengakuan penghasilan antara laporan keuangan komersial dan laporan keuangan fiskal, sedangkan perbedaan tetap adalah perbedaan treatment atas pembebanan biaya dan pengakuan penghasilan antara laporan keuangan komersial dan laporan keuangan fiskal. Penjelasan lebih lanjut mengenai area perbedaan laporan keuangan sebagai berikut :

1) Perbedaan Waktu.Beberapa faktor yang jelas-jelas menyebabkan terjadinya perbedaan waktu, antara lain adalah: Depresiasi 


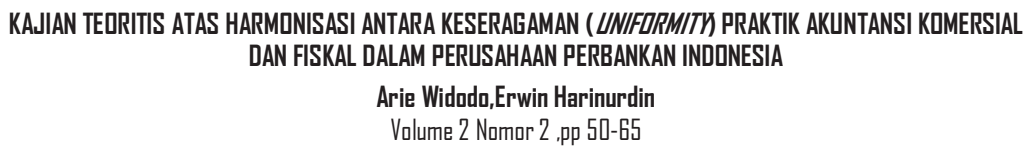

(Penyusutan) Aktiva Berujud dan Amortisasi Aktiva Sumber Alam \& Aktiva Tak Berujud. Depresiasi (Penyusutan) Aktiva berwujud merupakan jumlah yang dapat disusutkan (depreciable amount) dari suatu aktiva yang dialokasikan berdasar suatu dasar yang sistematis dan beralasan selama masa manfaat aktiva tersebut. Biaya depresiasi ini menjadi penyebab beda waktu karena terdapat beberapa metode yang berbeda yang dianut oleh akuntansi dan oleh perpajakan sehingga membuat pengalokasian ke masing-masing tahun berbeda meskipun jumlah totalnya menjadi sama. Perbedaan biaya ini hanya berpengaruh pada laba rugi perusahaan antar satu periode dengan periode lainnya tetapi jumlah keseluruhan yang dapat disusutkan tersebut akhirnya akan dinikmati pula oleh periode-periode selama masa manfaat aktiva tersebut.

Sehingga setelah masa manfaat aktiva tersebut berakhir jumlah pengurang penghasilan (biaya) akan sama, dialokasikan dengan jumlah yang berbeda untuk setiap periodenya. Perbedaan jumlah yang dialokasikan tersebut tergantung pada faktor penentu depresiasi. Perbedaan faktor penentu depresiasi menurut akuntansi dan perpajakan adalah: a) metode depresiasi, b) penentuan masa manfaat aktiva tetap, c) perlakuan nilai residu (nilai sisa). 2) Penilaian Persediaan. Dalam perpajakan, persediaan dan pemakaian persediaan untuk penghitungan harga pokok dinilai berdasarkan harga perolehan secara rata-rata (average) atau dengan cara mendahulukan persediaan yang diperoleh pertama yang disebut dengan FIFO (First In First Out)/ MPKP (Masuk Pertama Keluar Pertama). Dalam akuntansi banyak metode bisa digunakan untuk menentukan besarnya persediaan dan harga pokok penjualan, diantaranya adalah metode FIFO/MPKP, LIFO (Last In First Out)/MPKT (Masuk Pertama Keluar Terakhir), Rerata Tertimbang atau metode lain. Beda waktu terjadi jika pendekatan untuk membuat laporan keuangan komersial berbeda dengan kepentingan fiskal. 3).Penghapusan Piutang
Standar Akuntansi Keuangan menyatakan bahwa "piutang dinyatakan sebesar jumlah kotor tagihan dikurangi dengan taksiran jumlah yang tidak dapat ditagih. Jumlah kotor piutang harus tetap disajikan pada neraca diikuti dengan penyisihan untuk piutang yang diragukan atau taksiran jumlah yang tidak dapat ditagih ". Dalam akuntansi sendiri sebenarnya dikenal dua metode penghapusan piutang, yaitu: metode langsung dan metode cadangan. Dalam metode langsung, kerugian piutang baru diakui pada waktu diketahui ada piutang yang benar-benar tidak dapat ditagih sesuai dengan kebijakan perusahaan atau pernyataan debitur. Dengan demikian pengakuan kerugian piutang sebagai pengurang pendapatan baru dilakukan pada tahun terjadinya penghapusan piutang tersebut. Dalam metode cadangan, pada setiap akhir suatu periode dibentuklah cadangan kerugian piutang untuk menaksir jumlah piutang yang sekiranya tidak dapat ditagih pada periode berikutnya. Pada saat pembentukan cadangan ini perusahaan mengakui adanya kerugian piutang sedangkan pada saat benar benar terjadi piutang yang tidak tertagih (piutang harus dihapus) maka tidak lagi mengakui adanya kerugian piutang tetapi hanya menghapus piutang dan membebankannya ke rekening cadangan kerugian piutang yang telah dibentuk sebelumnya.

Pernyataan SAK di atas mengandung makna agar akuntansi di Indonesia menganut metode cadangan dalam penghapusan piutang. Dalam perpajakan, salah satu komponen tidak diperbolehkan sebagai pengurang penghasilan dalam menentukan besarnya Penghasilan Kena Pajak adalah pembentukan atau pemupukan dana cadangan kecuali cadangan piutang tak tertagih untuk usaha tertentu seperti usaha bank dan sewa guna usaha dengan hak opsi, usaha asuransi, usaha pertambangan sebagai cadangan biaya reklamasi. Piutang akan dihapus dan diakui sebagai kerugian piutang pada saat atau periode dimana piutang tersebut nyata-nyata tidak dapat ditagih. Hal ini berarti metode 
yang dianut adalah penghapusan piutang langsung.

\section{Perbedaan permanent}

Beberapa faktor yang menyebabkan terjadinya perbedaan permanen dikelompokkan ke dalam:

1. Adanya penghasilan yang merupakan obyek pajak yang bersifat final, meliputi: Penghasilan bunga deposito dan tabungan lainnya, penghasilan karena transaksi penjualan saham dan sekuritas lainnya di bursa efek, penghasilan dari pengalihan hak atas tanah/atau bangunan, penghasilan dari hadiah undian, penghasilan bunga atas diskonto obligasi yang dijual di bursa efek, penghasilan sewa (tanah/atau bangunan), dan lainnya. Beberapa contoh penghasilan tersebut menurut akuntansi akan ditambahkan pada laba usaha dalam periode direalisasikannya penghasilan tersebut sehingga dalam laporan laba ruginya, pos pendapatan akan ditambah dengan jumlah penghasilan-penghasilan di atas sebagai kelompok pendapatan di luar usaha. Sedangkan dalam perpajakan, tidak lagi digabungkan dengan pos penghasilan bruto karena sudah dikenakan pajaknya langsung pada saat penghasilan itu terjadi (dengan tarip tertentu) oleh pemungut/pemotongnya.

Jumlah penghasilan tersebut tidak perlu dimasukkan sebagai penghitungan laba kena pajak dan jumlah pajak yang telah dibayarkan tersebut berarti tidak bisa dikreditkan dengan pajak yang terutang, inilah yang selanjutnya dikatakan bersifat final. Akibat dari perlakuan penghasilan ini akan menghasilkan penghitungan laba rugi yang berbeda antara pendekatan fiskal dengan pendekatan komersial - laba sebelum pajak lebih besar dibandingkan dengan laba kena pajak.

2. Aktiva lebih besar atau utang lebih kecil menurut komersial dibanding menurut fiskal. Beberapa contoh pendapatan tersebut bukan sebagai penghasilan dalam perpajakan tetapi dalam akuntansi termasuk kelompok penghasilan. Akibat dari perlakuan penghasilan ini akan membuat penghitungan laba rugi menurut fiskal berbeda dengan menurut komersiallaba sebelum pajak lebih besar daripada laba kena pajak. Aktiva (Utang) menurut komersial lebih besar (kecil) dibanding dengan Aktiva (utang) menurut fiskal. Penyesuaian terhadap laporan keuangan komersial adalah:

- Laba sebelum pajak dalam laporan laba rugi komersial dikurangi dengan sejumlah penghasilan di atas untuk menghitung laba kena pajak dalam menyusun laporan laba rugi fiskal.

- Aktiva (utang) dalam neraca komersial dikurangi (ditambah) dengan sejumlah penghasilan di atas untuk menyusun neraca fiskal.

- Laba sebelum pajak dalam laboran laba rugi komersial ditambah dengan sejumlah biaya di atas untuk menghitung laba kena pajak dalam menyusun laporan laba rugi fiskal.

- Aktiva (utang) dalam neraca komersial ditambah (dikurangi) dengan sejumlah biaya di atas untuk menyusun neraca fiskal.

\section{Perbedaan lain-lain (other differences)}

Faktor pembeda yang ketiga terdiri dari:

1. Kerugian usaha dalam negeri. Jika suatu perusahaan menderita kerugian dalam suatu tahun tertentu maka sejumlah kerugian tersebut - menurut ketentuan perpajakan - dapat dikompensasikan pada periode berikutnya maksimal lima tahun. Akuntansi di Indonesia tidak secara jelas mengatur dapat tidaknya kerugian usaha dapat dikompensasikan ke periode sebelum atau sesudahnya.

2. Penggabungan penghasilan dalam menentukan kredit pajak maksimal untuk laba atau rugi usaha di luar negeri. Dengan dasar akrual (yang dianut akuntansi) maka jumlah pendapatan yang dilaporkan dalam laporan laba rugi komersial adalah berdasar pada waktu terjadinya pendapatan 
tersebut tanpa memandang kas sudah diterima atau belum. sedangkan dalam perpajakan, penggabungan penghasilan berasal dari luar negeri dilakukan dengan ketentuan sebagai berikut:

1. untuk penghasilan dari usaha dilakukan dalam tahun pajak diperolehnya penghasilan tersebut;

2. untuk penghasilan lainnya dilakukan dalam tahun pajak diterimanya penghasilan tersebut;

3. untuk penghasilan berupa dividen atas penyertaan saham lebih dari 50\% dari jumlah modal disetor dilakukan berdasar Keputusan Menteri Keuangan RI.

3. Penghasilan Tidak Kena Pajak (PTKP). Untuk Wajib Pajak orang pribadi, yang menggunakan pembukuan maka penghasilan atau laba menurut penghitungan pembukuan tersebut masih dikurangi dengan Penghasilan Tidak Kena Pajak sesuai dengan kondisi Wajib Pajak yang bersangkutan untuk menentukan Penghasilan (Laba) Kena Pajak. Penyesuaian untuk kondisi ini adalah: laba sebelum pajak dikurangi dengan PTKP.

4. Investment Tax Credit, merupakan pengurangan sejumlah tertentu dari pajak penghasilan yang terutang untuk mendorong tumbuhnya investasi di bidang-bidang tertentu. Perlakuan Investment Tax Credit itu sendiri ada dua yaitu dengan differred method dan flow through metod, tetapi perbedaan keduanya tidak menyebabkan adanya perbedaan laba kena pajak dan laba sebelum pajak. Metode inipun belum diatur dalam SAK. UU Pajak Penghasilan di Indonesia juga tidak mengenal fasilitas kredit pajak investasi. Fasilitas kepada perusahaan yang melakukan investasi dalam bidang usaha, dan daerah tertentu berupa memperhitungkan depresiasi aktiva tetapnya (golongan I) berdasar tarip sebesar 100\% (saldo menurun).
5. Preferential Tax Rate: perbedaan karena tarip pajak final dan tarip pajak progresif. Di Indonesia pajak hanya dikenal/diatur dalam aturan perpajakan sehingga tidak mengenal perbedaan karena tarip pajak menurut akuntansi dan menurut perpajakan.

\section{Harmonisasi Laporan Keuangan Perusahaan Perbankan di Indonesia.}

Kegiatan usaha perbankan di Indonesia mengalami perkembangan yang semakin komplek dan pesat. Dinamisasi perkembangan tersebut berjalan seiring dengan berbagai faktor yang mempengaruhinya, seperti perubahan regulasi, perkembangan teknologi, perkembangan produk dan tuntutan pelanggan.

Perkembangan kegiatan usaha tersebut agar dapat berjalan dengan baik memerlukan berbagai infrastruktur pendukung yang memadai. Salah satu bentuk infrastruktur yang diperlukan adalah ketentuan-ketentuan yang terkait dengan akuntansi. Akuntansi dipandang sebagai salah satu infrastruktur yang penting karena melalui proses akuntansi inilah seluruh kegiatan, khususnya yang bersifat kuantitatif, akan didokumentasikan. Selanjutnya, melalui proses akuntansi ini, juga akan dihasilkan suatu laporan keuangan yang sangat berguna sebagai dasar untuk pengambilan keputusan para stakeholder perbankan.

Laporan keuangan yang dapat digunakan untuk pengambilan keputusan usaha harus memiliki kualitas yang baik. Suatu laporan keuangan dikatakan berkualitas jika memenuhi syarat karakteristik kualitatif laporan keuangan yang terdiri dari andal, relevan, dapat diperbandingkan (comparability), dan dapat dipahami (understandability). Untuk mencapai kualitas tersebut, suatu laporan keuangan harus disusun berdasarkan prinsip-prinsip akuntansi yang berlaku umum (PABU). Pondasi utama dari PABU di Indonesia adalah kerangka dasar (conceptual framework), Pernyataan Standar Akuntansi Keuangan (PSAK) dan 
interpretasinya. Sejalan dengan hal tersebut di atas dan terkait dengan penerapan revisi PSAK 50 (Revisi 2006): Instrumen Keuangan: Penyajian dan Pengungkapan dan PSAK 55 (Revisi 2006): Instrumen Keuangan: Pengakuan dan Pengukuran, maka menjadi sangat penting untuk menjadi Pedoman Akuntansi Perbankan Indonesia (PAPI).

Pengambilan keputusan ekonomi tidak dapat semata-mata didasarkan atas informasi yang terdapat dalam laporan keuangan. Hal ini disebabkan laporan keuangan memiliki keterbatasan, antara lain:

1. Bersifat historis yang menunjukkan transaksi dan peristiwa yang telah lampau.

2. Bersifat umum, baik dari sisi informasi maupun manfaat bagi pihak pengguna. Biasanya informasi khusus yang dibutuhkan oleh pihak tertentu tidak dapat secara langsung dipenuhi sematamata dari laporan keuangan saja.

3. Tidak luput dari penggunaan berbagai pertimbangan dan taksiran.

4. Hanya melaporkan informasi yang material.

5. Bersifat konservatif dalam menghadapi ketidakpastian. Apabila terdapat beberapa kemungkinan yang tidak pasti mengenai penilaian suatu pos, maka dipilih alternatif yang menghasilkan laba bersih atau nilai aset yang paling kecil.

6. Lebih menekankan pada penyajian transaksi dan peristiwa sesuai dengan substansi dan realitas ekonomi dan bukan hanya bentuk hukumnya (formalitas).

7. Adanya berbagai alternatif metode akuntansi yang dapat digunakan sehingga menimbulkan variasi dalam pengukuran sumber daya ekonomis dan tingkat kesuksesan antar-bank.

Walaupun akuntansi mempunyai pengaruh yang sangat besar dalam pajak namun terdapat banyak perbedaan antara akuntansi pajak dan pajak. Perbedaan itu timbul karena adanya perbedaan tujuan antara pajak dan akuntansi. Tujuan utama akuntansi keuangan adalah untuk menyediakan informasi yang berguna kepada manajemen, para pemegang saham, para kreditur dan pihak-pihak lain yang berkepentingan. Tanggung jawab utama akuntan adalah melindungi pihak-pihak yang berkepentingan tersebut. Sebaliknya tujuan utama sistem pajak adalah pemungutan pajak secara adil. Tujuan utama instansi perpajakan adalah melindungi kepentingan masyarakat pajak.

Persamaan antara akuntansi pajak dan akuntansi keuangan menyangkut beberapa unsur yaitu kapitalisasi, realisasi, penyusutan, persediaan, utang-piutang, metode kas. Hubungan antara akuntansi keuangan dan akuntansi pajak di masing-masing Negara berbeda-beda tergantung pada ketentuan pajak di negara yang bersangkutan.

Dalam praktik akuntansi komersial dan fiskal dalam industri perbankan sudah terdapat uniformity untuk beberapa hal khusus, yaitu :

1. Pembayaran kembali oleh debitur.

Peraturan perpajakan khusus perbankan di Indonesia beberapa sudah mengatur terkait dengan harmonisasi dengan akuntansi keuangan. Salah satunya adalah terkait dengan penghapusan piutang tak tertagih. Peraturan Menteri Keuangan Nomor 57/PMK.03/2010 dalam pasal 5A menyebutkan bahwa apabila piutang yang nyata-nyata tidak dapat ditagih yang telah dibebankan sebagai biaya dalam penghitungan penghasilan kena pajak ternyata dibayar seluruhnya atau dibayar sebagian oleh debitur maka jumlah piutang yang dibayar seluruhnya atau dibayar sebagian tersebut merupakan penghasilan bagi kreditur pada tahun pajak diterimanya pembayaran.

2. Pengakuan Pendapatan bunga kredit nonperforming

Dalam PSAK No. 31 (Instrumen Keuangan

: Pengungkapan) disebutkan bahwa pendapatan dan beban bunga diakui secara akrual (accrual basis), kecuali pendapatan bunga dari kredit dan aktiva produktif lainnya yang non-performing. Pendapatan dari aktiva yang non performing hanya boleh diakui apabila pendapatan tersebut 


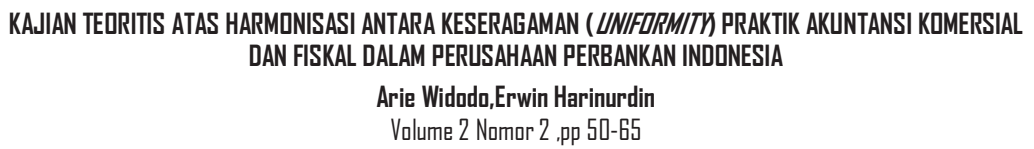

benar-benar telah diterima. Pendapatan dari aktiva produktif non-performing yang belum diterima tidak dapat diakui sebagai pendapatan dalam periode laporan dan harus dilaporkan dalam Laporan Komitmen dan Kontinjensi. Pemerintah melalui Direktorat Jenderal Pajak merasa perlu untuk menetapkan Keputusan Direktur Jenderal Pajak tentang pengakuan penghasilan atas penghasilan bank berupa bunga kredit non performing. Pada tanggal 11 April 2002 diterbitkan Keputusan Direktur Jenderal Pajak Nomor KEP-184/PJ./2002 yang menjelaskan bahwa kredit non-performing adalah kredit yang diberikan oleh bank yang digolongkan sebagai kredit kurang lancar, diragukan, dan macet. Penghasilan bank berupa bunga kredit non-performing diakui pada saat penghasilan bunga tersebut diterima oleh bank (cash basis). Dalam hal bank membukukan penerimaan bunga kredit non-performing sebagai pengurang pokok kredit maka saat pengakuan penghasilan ditunda hingga saat diterimanya penghasilan bunga setelah pelunasan pokok kredit.

\section{Selisih kurs mata uang asing}

Transaksi perbankan tidak terlepas dari transaksi dengan mata uang selain rupiah. Pemberian kredit kepada nasabah bisa dalam bentuk rupiah atau mata uang selain rupiah. Pemberian kredit juga sangat tergantung dengan pemenuhan kebutuhan nasabah dan ketercukupan dana mata uang asing di bank tersebut. Pelunasan pinjaman secara bertahap oleh nasabah disepakati ketika perjanjian pinjaman dilakukan oleh keduabelah pihak dengan memperhatikan kurs mata uang asing pada saat pelunasan. Pelunasan pinjaman dengan mata uang asing dapat menimbulkan selisih kurs mata uang asing baik laba maupun kerugian.

Perlakuan perpajakan atas laba atau kerugian selisih kurs sebelum tahun 2009 mengatur bahwa laba atau kerugian selisih kurs mata uang asing yang disebabkan oleh fluktuasi kurs, pengakuan pendapatan atau pembebanan biaya dilakukan berdasarkan sistem pembukuan yang dianut, dan harus dilakukan secara taat asas. Apabila Wajib Pajak menggunakan sistem pembukuan berdasarkan kurs tetap (kurs historis), pembebanan kerugian selisih kurs dilakukan pada saat terjadinya realisasi atas perkiraan mata uang asing tersebut. Sedangkan apabila Wajib Pajak menggunakan sistem pembukuan berdasarkan kurs tengah Bank Indonesia atau kurs yang sebenarnya berlaku pada akhir tahun, pembebanannya dilakukan pada setiap akhir tahun berdasarkan kurs tengah Bank Indonesia atau kurs yang sebenarnya berlaku pada akhir tahun. Namun sejak tahun 2009, laba atau kerugian karena fluktuasi kurs mata uang asing diakui berdasarkan sistem pembukuan yang dianut dan dilakukan secara taat asas sesuai dengan Standar Akuntansi Keuangan yang berlaku di Indonesia.

\section{PENUTUP}

\section{Simpulan}

Perubahan kebijakan akuntansi dilakukan hanya jika penerapan suatu

kebijakan akuntansi yang berbeda diwajibkan oleh peraturan perundangan

atau standar akuntansi keuangan yang berlaku. Jika diperkirakan

bahwa perubahan tersebut akan menghasilkan penyajian kejadian atau

transaksi yang lebih sesuai dalam laporan keuangan suatu perusahaan maka perubahan kebijakan akuntansi tersebut lebih melihat kegunaanya dalam suatu perusahaan bukan dengan tujuan perpajakannya.

\section{Saran}

Kebijakan pajak kiranya dapat mempertimbangkan faktor uniformity. Artinya, setiap peraturan pajak dapat diterapkan dengan memperhatikan masalah kompleksitas yang muncul. 


\section{DAFTAR PUSTAKA}

Anselm Strauss \& Juliet Corbin, Dasar-dasar Penelitian Kualitatif: Tata Langkah dan Teknik-teknik Teoritisasi Data, terjemahan Muhammad Shodiq \& Imam Muttaqien, Pustaka Pelajar, Yogyakarta, 2003, hal 5

Asikin, et. al.,(1991) Pajak, Citra dan Upaya pembaharuannya : Pokok-pokok Pemikiran Salamun A.T (Jakarta : Bina Rena Pariwara), Hal. 185

Angel Q Yoingco, (1997) "Taxation in the Asia Pacific Region : A Salute to the Years of Regional Cooperation in Tax Administration and Research", Study Group in Asian Tax Adminisration \& Research, manila.

Berger and Mester L J, 1997,"'Inside the black box: What explains differences in the efficiency of financial instructions? Journal of Banking and Finance, 21, 895-947.

Donal E Kieso and jerry J Weygandts, Intermediate Accounting, 8th Edition, (John Wiley \& Sons, Inc, : New York, 1995), dan Ikatan Akuntan Indonesia, Standar Akuntansi Keuangan, Jakarta : Salemba Empat, 2004, hal 22.

Dendawijaya, Lukman, Manajemen Perbankan (Bogor : Penerbit Ghalia Indonesia, 2001) hal 12.

Gunadi. 1997. Akuntansi Pajak . Penerbit PT. Grasindo. Jakarta.

Gunadi, 1997, Pajak Internasional, jakarta : Lembaga Penerbit fakultas Ekonoi Universitas Indonesia.

Gunadi, 2004, Bunga Rampai Pemeriksaan Penyidikan \& Penagihan Pajak, Jakarta : MUC Publishing.

Harahap, Sofyan Syafri, 1999, Teori Akuntansi, Jakarta, PT Raja Grafindo Persada

Henri de Feydeau and Francois Kulbokas, "A national Report of Administrative and Tax compliance in France", dalam Cedric Sandford, (ed), Administrative and Tax compliace (Rotterdam, Netherland : Kluwer Law and Taxation Publishers, 1989) hal 361-386

Ikatan Akuntan Indonesia, (2004), Standar Akuntansi Keuangan: Buku Satu dan Dua, Jakarta: Penerbit Salemba Empat.

Irawan, Prasetya 2004, Logika dan Prosedur Penelitian, Pengantar Teori dan Panduan Praktik Penelitian Sosial bagi mahasiswa dan Peneliti Pemula, Jakarta : STIA LAN Press.

Irawan, Prasetya, 2006, Penelitian Kualitatif dan Kuantitatif untuk Ilmu-ilmu Sosial, jakarta : Departemen Ilmu Administrasi-FISIP UI.

Lilian F Mills, "Corporate tax Compliance and Financial Reporting" National tax Journal, Sept 1996, hal 431

Mansury R, The Indonesian Income Tax, A Case Study in Tax Reform of A Developing Countries, Asian Pacific Tax and Investment Research Centre, Singapore 1992. 
, Panduan Konsep Utama Pajak Penghasilan Indonesia, PT. Bina Rena Pariwara, Jakarta 1994

, Pajak Penghasilan Lanjutan, Indonesia Hill-Co, Jakarta 1996.

, Kebijakan Perpajakan, PT Bina Rena Pariwara, Jakarta, 2000.

Neuman, W Lawrence, 1999, Social Research Methods, Qualitative and Quantitative Approaches, United States of America : Allyn and bacon, Inc.,

Prasetyo, Adinur, 2007, Pengaruh Harmonisai Praktik Akuntansi Komersial dan Fiskal serta Kesamaan Persepsi Wajib Pajak dan Fiskus dalam Penafsiran Peraturan Perpajakan dan Ukuran Perusahaan Terhadap Biaya Kepatuhan Pajak dalam Rangka Optimasi Kepatuhan Pajak pada Perusahaan Masuk Bursa, Disertasi UI.

Prasetya Irawan, Logika dan Prosedur Penelitian: Pengantar Teori dan Panduan Praktika Penelitian Sosial bagi Mahasiswa dan Peneliti Pemula, STIA Lan Press, Jakarta, 2004 hal. 99

Reporting by the Working Group on Accounting Standar, 1987, The Relation between Taxation and Financial Statement : Income Taxation Accounting No. 3 OECD

Slamet Sugiri, (1997), "Prosedur Alokasi PPh Menurut SFAS 96", Kajian Bisnis, Yogyakarta: STIE Widya Wiwaha.

Sandford, Cedric (1989). "Administrative and Tax Compliance Costs of taxation”. Dalam Sanford, Cedric (ed). Administrative and tax Compliance costs of taxation (Rotterdam, Netherland: Kluwer law and taxation Publhishers).

Sandford and J hasseldine (1992). The Compliance Costs of Business taxes in New Zealand (Wellington, New Zealand, Institute of Policy Studies, Victoria University of Wellington.

Silvani, Carlos. (1992). The Economic of Tax Compliance : facts and Fantasy. National Tax Journal, Slemrod, J. (1989). Complexity, Compliance Cost, and Tax Evasion. An Agenda for Compliance Research, Vol. 2. Philadelphia: University of Pensylvania Press.

Slemrod, Joe and marsha Blumenthal (1992). "The Compliance cost of the US : Individual Income Tax System : A Second Look After Tax Reform”. National Tax Journal, Jun.

Supriyanto, Eko B (ed), Budaya Kerja Perbankan: Jalan Lurus menuju Integritas (jakarta : penerbit Pustaka LP3ES Indonesia, 2006), hal 114-115

Tjahjono Achmad dan Husein F, Muhammad, (1997), Perpajakan, Edisi Pertama, Yogyakarta: UPP AMP YKPN.

Weill, 2003, Banking efficiency in transaction economies: The role of foreign ownership”. Economic of Transaction, 11 (3), 569-592.

Zaki Baridwan , (1993), Intermediate Accounting, Edisi 7, Yogyakarta: BPFE-UGM. 